\title{
GENÉTICA DE PEIXES NEOTROPICAIS. II. BIOLOGIA MOLECULAR DE PEIXES NEOTROPICAIS
}

\author{
NEOTROPICAL FISH GENETICS. II. MOLECULAR \\ BIOLOGY OF NEOTROPICAL FISH
}

\author{
Rodrigo Augusto Torres ${ }^{1,}$ Daniele Aparecida Matoso', \\ Roberto Ferreira Artoni ${ }^{3}$
}

1 Autor para contato: Universidade Federal do Paraná - UFPR, Departamento de Zoologia, Curitiba, PR, Brasil; e-mail: ratorres@ufpr.br

2 Universidade Estadual de Ponta Grossa - UEPG, Campus em Uvaranas, Laboratório de Citogenética, Ponta Grossa, PR; e-mail: danielematoso@yahoo.com.b

3 Universidade Estadual de Ponta Grossa - UEPG, Campus em Uvaranas, Departamento de Biologia Estrutural, Molecular e Genética, Ponta Grossa, PR, Brasil; (42) 220-3739; e-mail: rfartoni@uepg.br

Recebido para publicação em 09/06/2004

Aceito para publicação em 02/09/2004

\section{RESUMO}

Inúmeros trabalhos foram realizados com marcadores moleculares, nas 4 últimas décadas. Isso foi possível devido ao surgimento de sofisticadas técnicas de resolução de polimorfismos de proteínas e DNA. No que diz respeito aos peixes de água doce, cuja região neotropical é caracterizada como a mais diversificada em número de espécies e densidade populacional, a biologia molecular tem disponibilizado diversas ferramentas capazes de acessar a variação genética existente nesses grupos e relacioná-la a fatores ambientais e antrópicos. Dessa forma, tem-se verificado a emergência de artigos versando sobre variação genética, filogenética, filogeográfica, ecológica, dentre outros aspectos da dinâmica biológica dos peixes. O presente trabalho tem como objetivo apresentar uma revisão bibliográfica sobre as metodologias básicas de estudo da área de biologia molecular, frente às tendências gerais de análise em biologia evolutiva de peixes de água doce na região neotropical.

Palavras-chave: peixes, marcadores moleculares, região neotropical, biologia evolutiva

\begin{abstract}
Several studies with molecular markers have been reported in literature in
\end{abstract}


the last 4 decades. It was possible due to the appearance of sophisticated techniques for polymorphism resolution of proteins and DNA. In relation to the fresh water fish, whose neotropical region is characterized as the most diversified in number of species and populational density, the molecular biology presents several tools capable of accessing the genetic variation in these groups and its correlation to the environment and antropic factors. Therefore, there have been verified the appearance of a great number of papers about genetic variation, phylogenetic, phylogeography, ecology, among other aspects of biological dynamics of the fish. The main purpose of the present work is to present a review of the basic methodologies of molecular biology studies, in relation to the general tendencies in evolutionary biology of neotropical fresh water fish.

Key words: fish, molecular markers, Neotropical region, evolutionary biology

\section{Introdução}

Segundo Lewinsohn e Prado (2002), o Brasil abriga a biota mais diversa entre os 17 países megadiversos do planeta. Os peixes se apresentam como os vertebrados mais diversificados e os de maior variação genética conhecida. Segundo Lowe-McConnell (1999), existem aproximadamente 20.000 espécies de peixes descritas atualmente e a maior parte habita águas quentes dos oceanos tropicais, perfazendo um total de $40 \%$. Os peixes de água doce são responsáveis por 20 a 25\% da biodiversidade de vertebrados e há indícios de que somente na América do Sul ocorram mais de 8.000 espécies, tendo em vista apenas duas das diversas ordens descritas (Characiformes e Siluriformes). Para Vari e Malabarba (1998), um percentual de 30 a $40 \%$ de toda a diversidade existente na ictiofauna Neotropical não foi até o momento reconhecida. Portanto, é principalmente nesse contexto de identificação da diversidade que estão sendo aplicados os marcadores genéticos e moleculares nas espécies de peixes neotropicais, buscando, inclusive, a exploração de características de interesse econômico, bem como a preservação de unidades evolutivamente significativas para a manutenção dessa biodiversidade (Ryder, 1986).

No final da década de 70, com a descoberta das enzimas de restrição, iniciaram-se os primeiros estudos com marcadores moleculares baseados em DNA. Nos anos subseqüentes, o desenvolvimento da genética de populações ganhou impulso com o uso dos mar- cadores RFLPs (Restriction Fragment Lenght Polymorphisms). Foi, no entanto, com o surgimento da técnica de PCR (Polymerase Chain Reaction) que os estudos nessa área ganharam considerável expressão (Avise, 1994).

A biologia molecular apresenta uma ampla área de atuação. Somente para a genética da conservação, tem possibilitado as estimativas de heterozigose, análise de estruturas familiares, ocorrência de endemismo, biodiversidade nominal, identificação e acompanhamento da dispersão de espécies invasoras (Solé-Cava, 2001).

O presente artigo tem como objetivo apresentar uma revisão bibliográfica sobre as metodologias básicas de estudo da área de biologia molecular e correlacionálas com as tendências e necessidades de estudos relativos ao entendimento, conservação, monitoramento e aproveitamento racional da diversidade da biota de peixes de água doce na região Neotropical.

\section{Marcadores baseados em proteínas}

A explicação do princípio de variação para os polimorfismos de isoenzimas é simples: as proteínas são cadeias de aminoácidos que refletem a expressão de um gene ativo no DNA. O método consiste basicamente no princípio de migração eletroforética das cadeias polipeptídicas (isoenzimas), quando submetidas a um campo elétrico. A substituição de um aminoácido na cadeia pode alterar seu ponto isoelétrico, bem como sua massa molecular, de tal forma que sua migração pode ser diferente, quando exposta a corrente elétrica, refletindo assim a ocorrência de variação na seqüência 
do gene.

O método é eficaz porque permite analisar um grande número de indivíduos e o custo é relativamente baixo. Entretanto, somente disponibiliza informações acerca de regiões codificantes do DNA, sendo necessária a consideração do estágio de desenvolvimento ontogenético do organismo. Além disso, as condições de voltagem aplicadas ao gel e o tempo de corrida variam de acordo com o tampão utilizado. O processo deve ser conduzido a baixas temperaturas e a quantidade de amostra deve ser suficiente para que a reação enzima-substrato possa ser detectada por técnicas citoquímicas. Pode ocorrer também a sub-estimativa da variabilidade genética, uma vez que nem toda mutação do DNA altera a estrutura protéica correspondente e nem toda substituição de aminoácidos altera a mobilidade eletroforética da enzima.

\section{Marcadores baseados em DNA e RNA}

A molécula de DNA (ácido desoxiribonucleico) é formada por três componentes químicos: um grupo fosfato, uma desoxirribose e uma base nitrogenada, os quais formam os nucleotídeos. Da organização linear dos nucleotídeos, que são pareados pela lei: A-T e C$\mathrm{G}$, tem-se a cadeia de DNA. O DNA é por-tanto uma molécula bifilamentar, composta por duas cadeias de nucleotídeos que estão interligadas através de pontes de hidrogênio efetuadas entre as bases complementares.

O DNA possui uma orientação particular que o capacita para a realização de importantes funções na célula, dentre elas a duplicação, bem como favorece a técnica de PCR (in vitro). Cada filamento serve de molde para a síntese de seu filamento complementar. O parea-mento estabelecido entre uma adenina e uma timina é feito por meio de duas pontes de hidrogênio, enquanto citosina e guanina o fazem compartilhando três pontes de hidrogênio. O diferencial de conteúdo AT/CG presente no DNA está diretamente associado à ela-boração deprimers para o estudo de genes específicos.

\section{Classes de DNA}

Marcadores moleculares baseados em DNA ou RNA, consistem na detecção de variações que ocorrem ao longo desses filamentos e que podem ser detectadas através de métodos específicos. Em relação ao DNA podem ser estudadas regiões codificantes, os genes propriamente ditos, e regiões não-codificantes, como as seqüências repetidas mini e microssatélites altamente variáveis e que geram os padrões DNA fingerprinting (impressão digital de DNA) usados na medicina forense, ou ainda regiões controles. Para o filamento de RNA os objetivos de estudo são focalizados principalmente nas moléculas de mRNA maduras que representam seqüências funcionais do genoma.

\section{DNA de cópia única}

Os genes que são normalmente transcritos em proteínas são representados por DNA de cópia única, sendo encontrados em extensões curtas entremeadas com diversas famílias de DNA repetitivo.

\section{DNA repetitivo}

As famílias de DNA repetitivo variam quanto à localização no genoma, comprimento total da série em tandem, e comprimento das unidades repetidas que constituem a série. Os DNAs satélites, são às vezes chamados VNTRs (Variable Number of Tandem Repeats). Os VNTRs podem compor a classe de DNA minissatélite, seqüências de 1 a 5 Kb que consistem em números variáveis de uma unidade repetida de 15 a 100 nucleotídeos de comprimento.

O DNA microssatélite, geralmente composto de repetições de dinucleotídeos, é também um tipo de DNA repetitivo constituído por regiões dispersas de números variáveis de repetições. Os elementos transponíveis ou transposons constituem uma grande proporção do genoma eucariótico composta de elementos repetitivos que evoluíram através da capacidade de se replicarem fazendo cópias de si mesmos e movendo-se para outras regiões do genoma. Os retrotransposons são uma classe de DNA que se propaga pela ação da enzima transcriptase reversa que tem a capacidade de fazer um filamento de DNA através de uma molécula RNA.

Aplicação de marcadores RAPDs e de seqüenciamento nos estudos populacionais e filogenéticos em peixes

O conjunto de métodos desenvolvidos para o estudo de genética de populações e de sistemática molecular (Hillis et al., 1996; Ferraris e Palumbi, 1996), tem conferido, na última década, uma vigorosa contribuição ao entendimento da fauna de peixes (Carvalho e Pitcher, 1995).

O primeiro estudo relativo ao reconhecimento da diversidade do genoma dos peixes foi desenvolvido por Bermingham e Avise (1986). Desde então, com a parceria de pesquisadores estrangeiros da área de 
genômica evolutiva e genética de populações, foi iniciado um forte processo de formação de cientistas brasileiros nessa área. Essas associações geraram uma crescente incorporação das metodologias de biologia molecular às práticas relativas à biologia evolutiva, ecologia, biogeografia, sistemática filogenética e conservação da fauna.

No tocante à ictiologia Neotropical, a primeira publicação relativa ao uso dessas metodologias para fins de entendimento da diversidade dessa fauna, foram as análises realizadas por Alves-Gomes et al. (1995). Esses autores, objetivando entender a evolução dos caracteres associados ao sistema eletrogênico e eletrosensorial da Ordem Gymnotiformes, utilizaram seqüências dos genes $16 \mathrm{~S}$ e 12S e os métodos de máximaparsimônia (MP), máxima-verossimilhança (ML) e evolução-mínima (ME), para elaborar uma análise filogenética. Os principais resultados foram: (1) a família Sternopygidae não é um grupo monofilético, sendo o gênero Sternopygus o único representante de uma única linhagem dentro da ordem; (2) a família Hypopopidae também não é monofilética e (3) a Ordem Gymnotiformes é composta por, no mínimo, seis clados naturais: Sternopygus, Apteronotidae, Electrophoridae, Gymnotidae e um novo clado formado pelos sternopygideos remanescentes + Hypopopidae + Rhamphichthyidae. Além disso foi sugerida uma nova família, Eigenmanniidae.

Após doze anos da publicação de Bermingham e Avise (1986) e cerca de 3 da publicação de AlvesGomes et al. (1995), tornou-se pública a primeira iniciativa de utilização de marcadores moleculares de DNA para o entendimento da distribuição geográfica e diversidade de peixes neotropicais de água doce. Dergam et al. (1998) utilizaram os padrões de similaridade genômica, baseados em marcadores RAPDs, (Random Amplified Polymorphism DNA) como forma de avaliar a diferenciação genética de Hoplias malabaricus (traíras) oriundas dos rios Iguaçu, Paraná e Tibagi que são bacias geograficamente vizinhas. Baseando-se nos dados obtidos, os autores sugeriram a ocorrência de uma forte estruturação populacional dessa espécie nos rios Paraná e Tibagi e ainda a ocorrência de unidades biológicas novas, ainda não descritas. Além disso, dada a extrema similaridade genética, as populações oriundas das nascentes dos rios Tibagi e Iguaçu parecem ter um dia constituído um único estoque genético, atualmente isolado geograficamente.

Marcadores $R A P D$ foram também eficientes na detecção dos níveis de variação genética populacional detectados por Wasko e Galetti (2002) e Hatanaka e Galetti (2003). Analisando populações de peixes migradores Brycon lundii eProchilodus marggravii, respectivamente, coletados na mesma bacia hidrográfica (São Francisco), esses autores postularam a ocorrência de modelos de estruturação genética para explicar os diversos níveis de variabilidade observados dentro e entre os sítios de coletas para ambas as espécies.

Marcadores $R A P D$ foram empregados para analisar populações de lambaris (Astyanax sp.) provenientes das Furnas do Parque Estadual de Vila Velha com o intuito de verificar os níveis de variação e diferenciação genética entre as mesmas e inferir sobre o possível isolamento geográfico e endemismo para a região (Matoso et al., 2004). Dergam et al. (2002), usando a mesma metodologia, bem como seqüências do gene mitocondrial 16S interpretaram as diferenças genéticas observadas em Hoplias malabaricus da bacia do rio Doce, sudeste do Brasil, como o resultado de processos evolutivos diversos, como pressão de seleção, deriva genética, vicariância e efeito fundador. De fato, esses autores constataram uma complexa história filogeográfica envolvendo a bacia do rio Doce e outras bacias adjacentes. A principal conclusão foi a de que a bacia do rio Doce compartilha uma história comum com as vertentes das bacias dos rios Paraíba do Sul e Grande, corroborando a hipótese de suas separações pela formação da Serra da Mantiqueira, durante o período Plio-Pleistoceno.

Os RFLPs (Restriction Fragment Lenght Ploymorphism) foram os marcadores usados por Moysés e Almeida-Toledo (2002), no estudo do genoma mitocondrial de cinco espécies de Astyanax das bacias hidrográficas do Alto Paraná e São Francisco. As autoras detectaram expressivo número de mutações pontuais em populações simpátricas e padrões espécie - específicos resultantes da digestão enzimática.

Almeida et al. (2003), objetivando gerar dados acerca da estruturação genética de populações, para os fins de orientação de condutas de conservação de peixes dos rios Tietê e Paranapanema no estado de 
São Paulo, estudaram amostras de Pimelodus maculatus (Siluriformes, Pimelodidae). As amostras foram coletadas em três pontos dos rios acima mencionados: alto, médio e baixo. As análises dos marcadores RAPDs revelaram a inexistência de estruturação genética para as amostras do rio Tietê, bem como entre aquelas nativas do médio e baixo Paranapanema. Por outro lado, foi constatada a ocorrência de uma diferenciação genética entre a amostra do alto Paranapanema e as demais do mesmo rio.

No tocante ao uso de seqüências de genes e métodos filogenéticos, como artifício de análises da diversidade da ictiofauna Neotropical, a publicação de Alves-Gomes et al. (1995) passa novamente a ser o ponto de partida. Além disso, as análises por seqüenciamento de regiões específicas do genoma nuclear ou organelar talvez seja a metodologia com maior expressão nos estudos envolvendo marcadores moleculares, porque acessa diretamente a variação em nível da molécula de DNA. Especificamente, estas abordagens permitem a identificação e a procedência de estoques populacionais, análise filogenética, análise de estruturas familiares, fluxo gênico e endemismo.

Dois anos mais tarde, Ortí e Meyer (1997), objetivando propor uma perspectiva molecular (DNA) sobre a filogenia da Ordem Characiformes, empregaram como ferramenta os limites de resolução das seqüências dos genes mitocondriais 12S e 16S. Esses autores puderam identificar regiões conservadas e variáveis para tais seqüências. Considerando a estrutura secundária proposta para essas seqüências, foi observada a ocorrência de uma extrema variação e conservação nas alças e ramos, respectivamente. Além disso, a ocorrência de alta proporção de substituições compensatórias nos ramos sugeriu uma forte seleção em favor da manutenção da estrutura secundária destas seqüências.

Sivasundar et al. (2001) utilizaram seqüências do genoma mitocondrial (ATPase subunidades 6 e 8) com o intuito de inferir as relações filogenéticas de espécies do gênero Prochilodus oriundos das bacias dos rios Paraná, Amazonas, Orinoco e Magdalena. Usando o gênero Semaprochilodus como um grupo externo, as análises mostraram que: (1) cada bacia hidrográfica possui um grupo monofilético de linhagens mitocondriais e, (2) a ordem dos ramos evolutivos colocou a bacia do rio Magdalena em uma posicão basal, com uma subseqüente evolução para as bacias do Orinoco, Amazonas e Paraná. Além desse achado, as seqüências da região controladora para 26 amostras de $P$. lineatus (bacias dos rios Paraná, Magdalena, Orinoco e Amazonas) revelaram uma divergência entre as sequiências de 0.3 até $3.6 \%$. A análise filogenética baseada nessas seqüências é bem resolutiva, porém não associada à geografia, uma vez que os haplótipos do alto rio Paraná (rio Mogi Guaçú) e do alto rio Bermejo (separados por cerca de 2.600 km) têm uma próxima relação genealógica.

Ainda em relação à utilização de seqüências gênicas, Prioli et al. (2002) usaram a região controladora do mtDNA de Astyanax altiparanae do rio Iguaçu para separar populações dessa espécie de populações de $A$. bimaculatus e verificar o nível de endemismo, isolamento geográfico e similaridade entre as populações. Assim, as seqüências mitocondriais revelaram alta diversidade genética dentro de cada população e baixa distância genética entre as mesmas, além de altos índices de fluxo gênico. Esses dados, bem como as similaridades morfo-anatômicas registradas, sugeriram que a população de Astyanax bimaculatus do rio Iguaçu deveria, na verdade, ser diagnosticada como de Astyanax altiparanae, possibilitando inferir que a população de A. altiparanae não é de fato endêmica do rio Iguaçu, mas deve ter sido introduzida recentemente nesse sistema hídrico, uma vez que é resguardada a sua identidade genética.

Montoya-Burgos (2003), objetivando testar o quanto as alterações paleohidrológicas causaram a diversificação da ictiofauna Neotropical, gerou uma hipótese hidrogeológica baseada nas relações filogenéticas de 51 espécies do gênero Hypostomus. Assim, a análise de seqüências da região controladora do mtDNA indicaram que Hypostomus pode ser dividido em quatro clados monofiléticos, fato que permitiu a identificação de sete principais eventos cladogenéticos associados, temporalmente, a alterações hidrogeológicas.

Em relação a espécies marinhas, Santos et al. (2003), procurando verificar a existência de diversificação populacional entre diferentes amostras de Macrodon ancylodon, ao longo da costa Atlântica da América do Sul, utilizaram seqüências dos genes 16S e citocromo B (mtDNA) como ferramenta para tais 
abordagens. As análises dessas seqüências revelaram, de maneira geral, a ocorrência de dois subgrupos, um tropical e outro subtropical, ambos fortemente suportados pelas seqüências dos dois genes, analisados independentemente. Além disso, os dados sugerem que podem estar existindo subestruturações genéticas internamente aos subgrupos tropical e subtropical, o que permite a orientação de condutas de conservação desses diferentes estoques observados.

Mais recentemente, Shimabokuro - Dias et al. (2004) obtiveram seqüências dos genes mitocondriais 12S rRNA, 16S rRNA, ND4, tRNA ${ }^{\text {His }}$ e tRNA ${ }^{\text {Ser }}$ de 12 espécies do gênero Corydoras, três de Aspidoras, duas de Brochis, Dianema, Lepthoplosternum e Megalechis, além de duas populações locais de
Callichthys e Hoplosternum. As comparações filogenéticas das seqüências com aquelas dos grupos externos (Nematogenys inermis/Nematogenyidae; Trichomycterus areolatus e Henonemus punctatus/ Trichomycteridae; Astroblepus sp./Astroblepidae e Neoplecostomus paranensis, Delturus parahybae e Hemipsilichthys nimius/Loricariidae) revelaram que a família Callichthyidae é monofilética e compreende dois grupos naturais: as subfamílias Corydoradinae (Aspidoras, Brochis, e Corydoras) e Callichthyinae (Callichthys, Dianema, Hoplosternum, Lepthoplosternum e Megalechis). Por outro lado, suas relações internas apresentaram-se bem diferentes daquelas baseadas em caracteres morfoanatômicos.

Tabela 1 - Estudos realizados nas duas últimas décadas com peixes neotropicais usando marcadores moleculares de DNA e suas respectivas bacias hidrográficas.

\begin{tabular}{|c|c|c|c|}
\hline GÊNERO/ ESPÉCIE & LOCALIDADE & MARCADOR & REFERÊNCIA \\
\hline Leporinus friderici & Guiana / Brasil & RFLP & Renno et al. 1990 \\
\hline Sternopugus Archolaemus & Rios Neotropicais & Seqüências $12 S$ e $16 S$ & $\begin{array}{l}\text { Alves-Gomes et al. 1995, } \\
\text { Alves-Gomes } 1998\end{array}$ \\
\hline Hoplias malabaricus & $\begin{array}{l}\text { Bacia do Iguaçu, Paraná e } \\
\text { Tibagi - Pr }\end{array}$ & RAPD & Dergam et al. 1998 \\
\hline Prochilodus & $\begin{array}{l}\text { Bacias do Paraná, Amazonas, } \\
\text { Orinoco e Magdalena }\end{array}$ & Sequêencias de mtDNA & Sivasundar et al. 2001 \\
\hline Astyanax altiparanae & Bacia do Iguaçu - Pr & $\begin{array}{c}\text { RAPD e Seqüências de } \\
\text { mtDNA }\end{array}$ & Prioli et al. 2002 \\
\hline Brycon lundii & Bacia do São Francisco & RAPD & Wasko e Galetti Jr. 2002 \\
\hline H. malabaricus & Bacia do Doce & RAPD, Seqüências 16S & Dergam et al. 2002 \\
\hline Pseudoplatistoma corruscans & Bacia do Paraná - Pr & RAPD & Prioli et al. 2002 \\
\hline Steindachnerina & Bacia do Paraná - Pr & RAPD & Oliveira et al. 2002 \\
\hline Astyanax & $\begin{array}{l}\text { Bacias do Paraná e São } \\
\text { Francisco }\end{array}$ & RFLP & $\begin{array}{l}\text { Moysés e Almeida Toledo } \\
2002\end{array}$ \\
\hline Prochilodus marggravii & Bacia do São Francisco & RAPD & Hatanaka e Galetti Jr. 2003 \\
\hline Hypostomus & Principais rios Neotropicais & Seqüências ITS & Montoya-Burgos 2003 \\
\hline Pimelodus maculatus & $\begin{array}{l}\text { Bacias do Tietê e } \\
\text { Paranapanema - SP }\end{array}$ & RAPD & Almeida et al. 2003 \\
\hline Leporinus elongatus & Bacia do Paraná - SP & Seqüências de mtDNA & Martins et al. 2003 \\
\hline Astyanax $s p$ & Bacia do Tibagi - Pr & RAPD & Matoso et al. 2004 \\
\hline $\begin{array}{l}\text { Corydoras, Aspidoras, Brochis, } \\
\text { Dianema, Lepthoplosternum, } \\
\text { Callicchthys e Hoplosternum }\end{array}$ & Sistema de rios brasileiros & Sequêencias de mtDNA & $\begin{array}{l}\text { Shimaburo - Dias et al. } \\
2004 \text { (in press) }\end{array}$ \\
\hline
\end{tabular}




\section{tecidos}

Cuidados com a amostragem e fixação de

Alguns cuidados básicos precisam ser tomados com as amostras quando se pretende aplicar métodos de análise molecular. Marcadores isoenzimáticos, por detectarem polimorfismos em enzimas, são fortemente influenciados pela temperatura e a quantidade da amostra. Os marcadores de DNA são menos sensíveis a alterações de temperaturas, no entanto o DNA está sempre exposto a uma gama de substâncias que podem afetar sua conformação, tal como o efeito de enzimas DNAses. O RNA, por ser uma molécula menos estável (fita simples de ácido ribonucleico), está sujeito a alterações mais graves, sendo rapidamente degradado quando submetido a leve agitação ou exposto a ação das RNAses. Para minimizar esses efeitos deve-se trabalhar sob baixas temperaturas, e com material previamente fixado. A melhor forma de se acondicionar amostras é colocá-las em uma solução de álcoois metanol:etanol, na proporção 1:1. O tecido deve conter um volume de $1 / 1 \mathrm{~cm}^{3}$ e para sangue deve-se utilizar um anticoagulante como o EDTA.

\section{Metodologia Fenol-associada (Sambrook e} Russell, 2001)

Coloque o tecido de tamanho aproximado 1/1 $\mathrm{cm}^{3}$ em um cadinho macerando-o com nitrogênio líquido, usando um bastão. Adicione $4 \mathrm{a} 5 \mathrm{ml}$ de solução

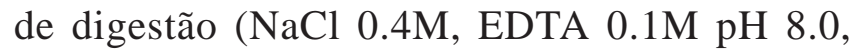
Proteinase K $100 \mu \mathrm{g} / \mathrm{ml}$, SDS 0,1\%). Transfira o material para um tubo de centrífuga tipo falcon e mantenha-o em banho-maria à temperatura de $50^{\circ} \mathrm{C}$, durante 1 hora e 30 minutos. Após esse tempo, trate o material com enzima RNAse $(100 \mathrm{mg} / \mathrm{ml})$ mantendo-o em banho-maria a $37^{\circ} \mathrm{C}$ por 1 hora. Proceda a uma leve agitação periódica. Adicione ao tubo uma solução de fenol: clorofórmio: álcool isoamílico (50:48:2) em volume igual ao da digestão. Agite suavemente o tubo por aproximadamente 30 minutos. Centrifugue o material por 10 minutos a 10.000 rpm, transfira com auxílio de micropipeta o sobrenadante para um tubo limpo, tomando cuidado para não ressuspender a camada fenólica. Acrescente $\mathrm{NaCl} 1 \mathrm{M}$ para a precipitação do DNA juntamente com 2 volumes de etanol absoluto gelado. Inverta o tubo diversas vezes. Centrifugue o material por 5 minutos a 10.000 rpm e descarte o sobrenadante. Adicione ao tubo aproximadamente $2 \mathrm{ml}$ de etanol 70\%, deixe descansar por 5 minutos, centrifugá-lo por 5 minutos a 10.000 rpm. Descarte o sobrenadante e seque o DNA em estufa a $37^{\circ} \mathrm{C}$ overnight. Elua o DNA seco em $500 \mu \mathrm{l}$ de tampão TE (Tris-HCl 10mM, EDTA $1 \mathrm{mM}$ ) e armazene-o à temperatura de $-20^{\circ} \mathrm{C}$ em tubos tipo eppendorf .

\section{Metodologia Salting-out - Fenol desassociada (Miller et al., 1988)}

Retire um fragmento de tecido de $0.5-1.0 \mathrm{~cm}^{3}$ e picote-o com uma lâmina estéril. Quanto mais fragmentado o tecido, melhor será o resultado da extração. Transfira o tecido para um tubo $(1.5-2.0 \mathrm{ml})$ e adicione $80 \mu \mathrm{l}$ do tampão da enzima (Proteinase K, 40 $\mu \mathrm{l}$ da solução de Proteinase K, $20 \mu \mathrm{l}$ SDS 20\%) e 240 $\mu \mathrm{H}_{2} \mathrm{O}$ ultra-pura autoclavada. Homogeneize em vortex por 25 segundos. Incube a solução em banhomaria ou estufa a $60^{\circ} \mathrm{C}$ por 2 horas. Use o vortex a cada 20 minutos. Retire a solução dos $60^{\circ} \mathrm{C}$ e deixea descansar por tempo suficiente para atingir a temperatura ambiente. Adicione à solução $100 \mu \mathrm{l}$ de $\mathrm{NaCl} 6$ M. Misture, batendo levemente no fundo do tubo. Centrifugue a solução a 13.000 rpm por 5 minutos. Transfira o sobrenadante para um tubo $(1.5-2.0 \mathrm{ml})$ novo e centrifugue a solução novamente à 13.000 rpm por mais 5 minutos. Transfira o sobrenadante para um tubo $(1.5-2.0 \mathrm{ml})$ novo e estéril e adicione $850 \mu \mathrm{l}$ de etanol absoluto gelado. Inverta o tubo gentilmente por várias vezes para precipitar o DNA. Centrifugue a solução à 13.000 rpm por 5 minutos. Despreze o sobrenadante e adicione $1 \mathrm{ml}$ de etanol $70 \%$ em temperatura ambiente e inverta o tubo gentilmente por várias vezes. Centrifugue a solução à 13.000 rpm por 5 minutos. Despreze o sobrenadante e deixe secar em temperatura ambiente. Ressuspenda o DNA em $50 \mu \mathrm{l}$ de $\mathrm{H}_{2} \mathrm{O}$ ultrapura e autoclavada e deixeovernight em temperatura ambiente para hidratar o DNA extraído. Verifique a integridade do DNA em gel de agarose 1\% a $60 \mathrm{~V}$ por 30 minutos e quantifique sua concentração por espectrofotometria.

Metodologia para nadadeiras e escamas Fenol associada (Wasko et al., 2003)

Retire pequenos fragmentos de nadadeiras e/ou escamas, a partir de amostras previamente preservadas em uma solução à base de etanol 95\% e EDTA 100 $\mu \mathrm{MpH}$ 8.0. Dissocie as amostras teciduais e as incube em 4 ml de tampão de digestão TNES - Uréia (10 
mM Tris-HCl pH 8.0; 125 mM NaCl; 10 mM EDTA pH 8.0; 0.5 \%SDS; 4M Uréia) em um tubo de 15 ml. Adicione à solução $30 \mu \mathrm{l}$ de RNase $(10 \mathrm{mg} / \mathrm{ml})$ e incube a mesma por 1 hora a $42^{\circ} \mathrm{C}$. Após esse período, adicione $30 \mu \mathrm{l}$ de uma solução de Proteinase K (10 mg/ $\mathrm{ml}$ ) e mantenha a solução nos mesmos $42^{\circ} \mathrm{C}$ por no mínimo mais 10 horas. Colha a solução e adicione $4 \mathrm{ml}$ de uma solução à base de fenol: clorofórmio: álcool isoamílico (25:24:1). Inverta gentilmente os tubos por 15 minutos e os centrifugue por 15 minutos a 10.000 rpm. Transfira o sobrenadante para um novo tubo limpo e autoclavado e precipite o DNA pela adição de um volume igual de $\mathrm{NaCl} 1 \mathrm{M}$ e dois volumes de etanol absoluto e gelado. Inverta a solução gentilmente por algumas vezes. Centrifugue a solução por 5 minutos a $10.000 \mathrm{rpm}$. O DNA deve ser lavado brevemente com etanol $70 \%$ por meio de inversões manuais; centrifugue e despreze o sobrenadante por meio de uma única inversão do tubo. Repita mais uma vez esse procedimento. Despreze o sobrenadante da forma anterior e deixe o DNA secar em temperatura ambiente. Ressuspenda o DNA extraído em 25 - $50 \mu \mathrm{l}$ de tampão TE (10 mM Tris HCl pH 8.0; 1 mM EDTA pH 8.0). Verifique a integridade do DNA em gel de agarose $1 \%$ a $60 \mathrm{~V}$ por 30 minutos e quantifique sua concentração por espectrofotometria.

\section{Extração de DNA - sangue (Lahiri e Nurnberger Jr., 1991)}

Colha a amostra de sangue total (cerca de 7 -8 $\mathrm{ml}$ ) usando EDTA como anticoagulante. Coloque o sangue em um tubo falcon e adicione três volumes de tampão A $\left(\mathrm{NH}_{4} \mathrm{HCO}_{3} 1 \mathrm{mM}, \mathrm{NH}_{4} \mathrm{Cl} 144 \mathrm{mM}\right)$. Mantenha a mistura no gelo ou no freezer por 10 minutos e descartar o sobrenadante. Adicione aopellet o mesmo volume de tampão A que fora utilizado anteriormente e homogeneize a amostra. Centrifugue a 2.000 rpm e despreze o sobrenadante. Repita esse processo de adição do tampão e centrifugação para que a amostra fique mais limpa. Em seguida despreze o sobrenadante e guarde a amostra em freezer $-20^{\circ} \mathrm{C}$, caso seja necessária a interrupção do processo. O próximo passo consiste em ressuspender o pellet leucocitário em $3 \mathrm{ml}$ de tampão B (Tris $10 \mathrm{mM}, \mathrm{NaCl}$ 400 mM, EDTA 2 mM) e adição de $200 \mu \mathrm{l}$ de SDS a $10 \%$. Adicione $2 \mu \mathrm{l}$ da enzima Proteinase K (30 mg/ ml) em 5 ml de tampão C (SDS 10\%, EDTA 0.5M) e acrescente $500 \mu \mathrm{l}$ dessa mistura no tubo contendo o DNA. Misture a amostra vigorosamente por 15 minutos. Deixe-a em repouso overnight à temperatura de $37^{\circ} \mathrm{C}$ ou a $60^{\circ} \mathrm{C}$ por uma hora. Adicione $1 \mathrm{ml} \mathrm{de} \mathrm{NaCl}$ a $6 \mathrm{M}$, deixando que o sal decante no fundo do tubo com posterior retirada do sobrenadante. Misture a amostra vigorosamente por 15 minutos e centrifugue a 2.000 rpm por 15 minutos. Recolha o sobrenadante, passando-o para um novo tubo. Centrifugue a amostra novamente para eliminação de resíduos. Adicione ao sobrenadante dois volumes de etanol 100\% e homogeneize a amostra. Centrifugue o tubo e descarte o sobrenadante lavando o material com etanol 70\%. Centrifugue o tubo, descartando o álcool. Deixe secar o DNA ressuspendendo-o em 200 a 500 ìl de TE, dependendo do tamanho dopellet.

\section{A técnica de $P C R$}

$P C R$ é uma sigla oriunda do inglês para a reação em cadeia que ocorre quando uma enzima especializada em copiar DNA é colocada sob condições ideais para realizar tal reação. A técnica foi descrita pelo cientista norte-americano Kary Mullis em 1993 (Sykes, 2003). O princípio se baseia na amplificação de um segmento de DNA, com o início da síntese começando em duas diferentes posições na molécula. A Reação em Cadeia da Polimerase (Polymerase Chain Reaction) tem como principal agente a enzima termo - sensível DNA Taq polimerase, que une nucleotídeos dispersos na reação para montar uma molécula, usando um DNA molde (DNA template). Uma PCR realiza-se em volumes muito pequenos entre 10 e 100 microlitros. Teoricamente é necessária apenas uma molécula-alvo de DNA para que a reação possa ocorrer. Os didesoxiribonucleotídeos trifosfatados (dATP, dTTP, dGTP, dTTP), são colocados em quantidades equimolares na reação. A concentração dos nucleotídeos varia de 50 a $200 \mathrm{M}$.

As concentrações de sais, como cloreto de potássio e sódio, podem interferir na reação aderindo-se a molécula de DNA. Outro fator relevante é a concentração do cloreto de magnésio um cátion divalente que funciona como co-fator enzimático para a Taq polimerase. A quantidade desses elementos deve girar em torno de $50 \mathrm{mM}$ para os sais de potássio e de sódio e $2.5 \mathrm{mM}$ para o magnésio. O pH ótimo para o funcionamento da enzima deve estar em torno de $7.5 \mathrm{e}$ 
a temperatura em $72^{\circ} \mathrm{C}$. A temperatura de desnaturação deve ser próxima dos $94^{\circ} \mathrm{C}$. O tempo de elongação depende do tamanho do fragmento a ser amplificado ficando em torno de 30 segundos a um minuto e o número de ciclos varia de 20 a 35 (Figura 1).

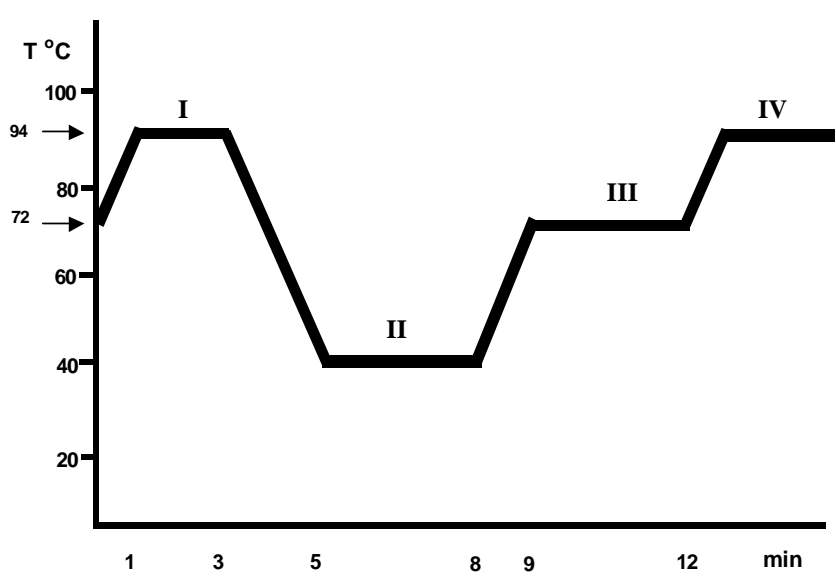

Figura 1 - Estágios de um ciclo de PCR. I - platô que indica a temperatura e tempo necessários para a desnaturação da dupla hélice de DNA, II - platô que indica a temperatura em que está ocorrendo a polimerização do DNA, III - platô que indica a polimerização final e o término de um ciclo, IV início de um novo ciclo de PCR.

\section{A técnica de RAPD (Welsh e McClelland (1990); Williamset al. (1990))}

A técnica de $R A P D$ (Figura 2) está baseada na amplificação do DNA genômico via PCR usando primers de seqüências nucleotídicas arbitrárias. Esta técnica possibilita detectar altos níveis de polimorfismos do DNA e conseqüentemente pode produzir marcadores genéticos espécie - específicos. Embora o potencial desse marcador no mapeamento genético populacional tenha sido documentado para uma grande variedade de organismos, incluindo os peixes, ele possui algumas limitações: demonstra herança dominante, ou seja, não separa organismos homozigotos dos heterozigotos, assume que as populações estão em Equilíbrio de Hardy - Weinberg e os alelos de diferentes loci não migram para a mesma posição no gel (Ferreira e Gratapaglia, 1996). Ressalta-se, porém, que o RAPD possui a vantagem de não requerer qualquer informação prévia do genoma que se pretende estudar, além disso, o uso de conjuntos de primers (Kits) aumentaram exponencialmente a eficiência da técnica para a obtenção de marcadores (bandas) espécie - específicos e devido a sua praticidade podem ser aplicados para um grande número de indivíduos sem onerar sobremaneira o estudo.

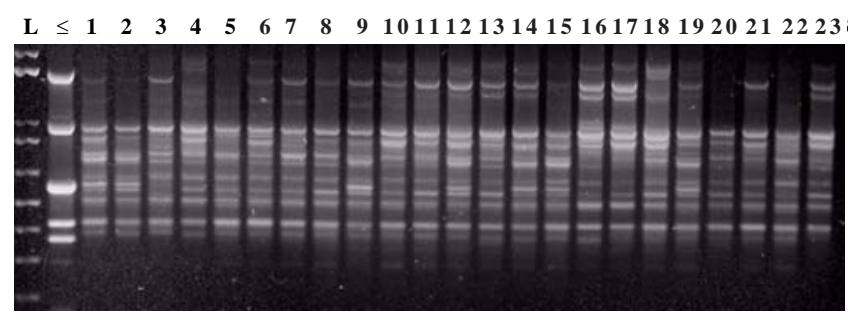

Figura 2 - Gel de RAPD de uma população de lambaris do gênero Astyanax. L = ladder (1.000 pb), d = lâmbda (DNA usado como controle positivo de reação).

A técnica de $R F L P$ (Grodzicker et al. (1974); Botstein et al. (1980); Wyman e White (1980) por PCR Mullis e Faloona (1987).

Para obtenção dos polimorfismos de tamanho dos fragmentos de restrição o DNA amplificado é digerido em soluções separadas para cada enzima de restrição a ser usada. O protocolo de digestão pode ser realizado como segue: $2 \mu \mathrm{l}$ de água milli Q, $0.5 \mu \mathrm{l}$ de solução tampão da enzima diluída $1 \mathrm{X}, 0.5 \mu \mathrm{l}$ da enzima de digestão (10 U/ $\mu$ l), $7 \mu \mathrm{l}$ de DNA (50 - 300 ng) e incubação overnight. O volume final de digestão, neste caso é $10 \mu \mathrm{l}$. Os produtos digeridos são visualizados em gel de agarose $2 \%$, corado com brometo de etídeo a $10 \mathrm{mg} / \mathrm{ml}$ e as imagens fotodocumentadas por um analisador de imagens (Figura 3).

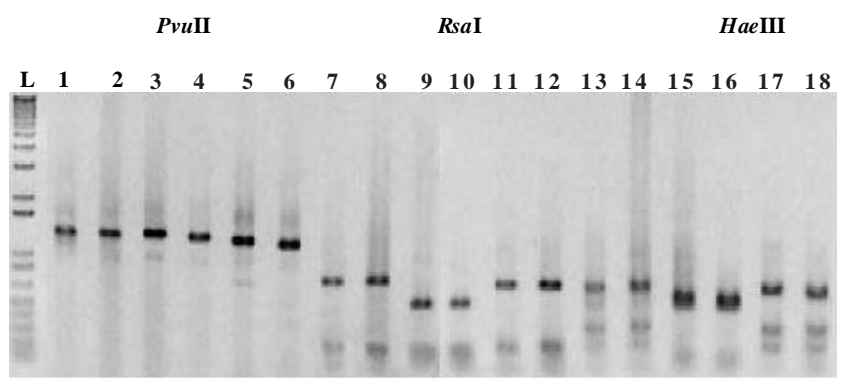

Figura 3 - Gel de RFLP de uma espécie de lambari do gênero Astyanax. PvuII (1-6), RsaI (7-12), and HaeIII (13-18). L = ladder (1.000 pb). 


\section{Perspectivas}

De acordo com Torres (2003), existe uma forte influência dos programas GENOMA brasileiros na formação de recursos humanos e tal influência tem permitido a incorporação dessas metodologias nos mais variados temas relacionados à biota neotropical. Dentre os diversos grupos biológicos e áreas de interesse, destaca-se a necessidade de ações de reconhecimento e conservação dessa biota, orientada por análises das características dos genomas de espécies e/ou populações.

Uma importante abordagem é a identificação e o entendimento do relacionamento das Unidades Evolutivamente Significativas - ESU (Ryder, 1986). Essas unidades, uma vez identificadas, permitem a previsão das prioridades de conservação, uma vez que se caracterizam como uma população, ou grupo de populações, que apresentam diferenciação morfológica, genética ou ecológica em relação a outras próximas, porém geograficamente isoladas (Torres, 2003). Ainda, segundo Moritz e Faith (1998), um critério genético na definição das ESUs seria: "tais unidades devem ser grupos monofiléticos para linhagens de mtDNA e devem apresentar significativas diferenças nas freqüências alélicas em loci nucleares”, o que parece bastante substancioso acerca da interpretação sobre o nível de distanciamento genético, filogenético e filogeográfico entre grupos populacionais (Torres, 2003).

\section{REFERÊNCIAS}

1 ALMEIDA, S. F.; SODRÉ, L. M. K. e CONTEL, E. P. B. Population structure analisys of Pimelodus maculatus (Pisces, Siluriformes) from Tietê and Paranapanema rivers (Brazil). Genet. Mol. Biol., v.26, n.3, p.301-305, 2003.

2 ALVES-GOMES, J.; ORTÍ, G.; HAYGOOD, M.; HEILIGENBERG, W. e MEYER, A. Phylogenetic analysis of the South American electric fishes (Order Gymnotiformes) and the evolution of their electrogenic system: a synthesis based on morphology, electrophysiology, and mitochondrial sequence data. Mol. Biol. Evol., v.12, n.2, p.298-318, 1995.

3 ALVES-GOMES, J. The phylogenetic position of south American electric fish genera Sternopygus and Archolaemus (Ostariophysi: Gymnotiformes) according to $12 \mathrm{~S}$ and $16 \mathrm{~S}$ mitochondrial DNA sequences. In: MALABARBA, L. R., REIS, E., VARI, R. P., LUCENA, Z. M. S., LUCENA, C. A. S. Phylogeny and Classification of Neotropical Fishes.
Edipucrs:Porto Alegre, 1998. p. 447-460.

4 AVISE, J. C. Molecular Markers, Natural History and Evolution. New York: Chapman and Hall, 1994.

5 BERMINGHAM, E. e AVISE, J. C. Molecular zoogeography of freshwater fishes in the southeastern United States. Genetics., n.113, p.939-965, 1986.

6 BOTSTEIN, D.; WHITE, R. L.; SKOLNICK, M. e DAVIS, R.W. Construction of a genetic linkage map in man using restriction fragment length polymorphism. Am. J. Hum. Genet., n.32, p.314-331, 1980.

7 CARVALHO, G. R. e PITCHER, T. J.Molecular Genetics in Fisheries. New York,Chapman and Hall, 1995.

8 CROUSE, J. e AMORESE, D. Ethanol precipitation: ammonium acetate as an alternative to sodium acetate. Focus, v.9, n.2, p.3-5, 1987.

9 DERGAM, J. A.; PAIVA, S. R.; SCHAEFFER, C. E.; GODINHO, A. L. e VEIRA, F. Phylogeography and RAPDPCR variation in Hoplias malabaricus (Bloch, 1794) (Pisces, Teleostei) in southeastern Brazil. Genet. Mol. Biol., n.25, p.379387, 2002.

10 DERGAM, J. A.; SUZUKI, H. I.; SHIBATTA, O.; DUBOC, L. F.; JÚLIO-JR, H. F.; GIULIANO-CAETANO, L. e BLACK IV, W. C. Molecular biogeography of the Neotropical fish Hoplias malabaricus (Erythrinidae: Characiformes) in the Iguaçu, Tibagi and Paraná rivers. Genet. Mol. Biol., v.21, n.4, p. 493496, 1998.

11 FERREIRA, M. E. e GRATTAPAGLIA, D. Introdução ao Uso de Marcadores Moleculares em Análise Genética. Brasília: Embrapa, 1996.

12 FERRARIS, J. D. e PALUMBI, S.R.Molecular Zoology. New York: Wiley-Liss, 1996.

13 GRODZICKER, T.; WILLIAMS, J.; SHARP, P. e SAMBROOK, J. Physical mapping of temperature-sensitive mutations of adenoviruses. Cold Spring Harbor Symp. Quant. Biol., n.39, p.439-446, 1974.

14 HATANAKA, T. e GALETTI Jr., P. M. RAPD markers indicate the occurrence of structured populations in a migratory freshwater fish species. Genet. Mol. Biol., n.26, p.1925, 2003.

15 LAHIRI, D. K. e NURNBERGER Jr., J. I. A rapid non enzimatic method for the preparation of HMW DNA from blood for RFLP studies. Nuc. Acids Res., v. 19, n. 9, p. 5444, 1991.

16 LEWINSOHN, T. M. e PRADO, P. I. Biodiversidade brasileira: síntese do estado atual do conhecimento. São Paulo: Editora Contexto, 2002.

17 LOWE-McCONNELL, R. H.Estudos Ecológicos de Comunidades de Peixes Tropicais. São Paulo: Editora da Universidade de São Paulo, 1999. 
18 MATOSO, D. A.; ARTONI, R. F. e GALETTI JR., P. M. Genetic diversity of the small characid fishAstyanax sp., and its significance for conservation. Hydrobiologia, n. 527:223225, 2004.

19 MARTINS, C.; WASKO, A. P.; OLIVEIRA, C. e FORESTI, F. Mitochondrial DNA variation in wild populations of Leporinus elongatus from the Paraná River basin. Genet. Mol. Biol., v.26, n.1, p.33- 38, 2003.

20 MILLER, S.A.; DYKES, D. D. e POLOLESKY, H. F. A simple salting out procedure for extracting DNA from human nucleated cells. Nucleic Acids Res., v.16, n.3, p.12-15, 1988.

21 MONTOYA-BURGOS, J. I. Historical biogeography of the catfish genus Hypostomus (Siluriformes: Loricariidae), with implications on the diversification of Neotropical ichthyofauna. Molecular Ecology, n.12, p.1855-1867, 2003.

22 MORITZ, C. e FAITH, D. P. Comparative phylogeography and the identification of genetically divergent areas for conservation. Molecular Ecology, n.7, p.419-429, 1998.

23 MOYSÉS, C. B. e ALMEIDA-TOLEDO, L. F. Restriction fragment length polymorphisms of mitochondrial DNA among five freshwater fish species of the genus Astyanax (Pisces, Characidae). Genet. Mol. Biol., n.25, p.401-407, 2002.

24 MULLIS, K. e FALOONA, F. Specific synthesis of DNA in vitro via polymerase catalysed chain reaction. Methods Enzymol., v.55, p. 335-350, 1987.

25 ORTÍ, G. e MEYER, A. The radiation of characiform fishes and the limits of resolution of mitochondrial ribossomal DNA sequences. Syst. Biol., v.46, n.1, p.75-100, 1997.

26 OLIVEIRA, A. .V.; PRIOLI, A. J.; PRIOLI, S. M. A. P.; PAVANELLI, C. S.; JÚLIO Jr., H. F. e PANARARI, R. S. Diversity and genetic distance in populations of Steindachnerina in the upper Paraná river floodplain of Brazil. Genetica, n.115p. 259-267, 2002.

27 PRIOLI, S. M. A. P.; PRIOLI, A. J.; JÚLIO Jr., H. F.; PAVANELLI, C. S.; OLIVEIRA, A. V.; CARRER, H.; CARRARO, D. M. e PRIOLI, L. M. Identification of Astyanax altiparanae (Teleostei, Characidae) in the Iguaçu River, Brazil, based on mitochondrial DNA and RAPD markers. Genet. Mol. Biol., n.25, p.421-430, 2002.

28 RENNO, J. R.; BERREBI, P.; BOUJARD, T e GUYOMARD, $\mathrm{R}$. Intraspecific genetic differentiation of Leporinus friderici (Anostomidae, Pisces) in French Guiana and Brazil: a genetic approach to the refuge theory. J. Fish Biol., n. 36, p. 85- 95, 1990.

29 RYDER, O. A. Species conservation and systematics: the dilema of subspecies. Trends Ecol. Evol., n.1, p.9-10, 1986.
30 SAMBROOK, J. e RUSSEL, D. W. Molecular Cloning. A Laboratory Manual. I, II, III, 3 ed. New York: Cold Spring Harbor Laboratory Press, 2001.

31 SANTOS, S.; SCHNEIDER H. e SAMPAIO, I. Genetic differentiation of Macrodon ancylodon (Sciaenidae, Perciformes) populations in Atlantic coastal waters of South America as revealed mtDNA analysis. Genet. Mol. Biol., v.26, n.2, p. 151-161, 2003.

32 SHIMABOKURO-DIAS, C. K.; OLIVEIRA C.; REIS, R. E. e FORESTI, F. Molecular phylogeny of the armored catfish family Callichthyidae (Ostariophysi, Siluriformes). Mol. Phylo. Evol., 2004 (in press).

33 SIVASUNDAR, A.; BERMINGHAM, E. e ORTÍ, G. Population structure and biogeography of migratory freshwater fishes (Prochilodus: Characiformes) in major South American rivers. Molecular Ecology, n.10, p. 407-417, 2001.

34 SOLÉ-CAVA, A. M. Biodiversidade molecular e genética da conservação. In: MATIOLI, S. R. Biologia Molecular e Evolução. Ribeirão Preto: Holos, 2001, p. 172-192.

35 SYKES, B. As Sete Filhas de Eva. A ciência que revela nossa herança genética. Rio de Janeiro: Record, 2003.

36 TORRES, R. A. New frontiers in conservation biology: the era of the genome. The Braz. J. Nat. Conserv., v.1, n.2, p.6062, 2003.

37 VARI, R. P. e. MALABARBA, L. R. Neotropical Ichthyology: An Overview. In: MALABARBA, L. R. Phylogeny and Classification of Neotropical Fishes. Porto Alegre: EDIPUCRS, 1998. 603p.

38 WASKO, A. P. e GALETTI Jr., P. M. RAPD analysis in Neotropical fish Brycon lundii: genetic diversity and its implications for the conservation of the species. Hydrobiologia, n.474, p.131-137, 2002.

39 WASKO, A. P.; MARTINS, C.; OLIVEIRA, C. e FORESTI, F. Non-destructive genetic sampling in fish. An improved method for DNA extraction from fish fins and scales. Hereditas, n.138, p.161-165, 2003.

40 WELSH, J. e McCLELLAND, M. Fingerprinting genomes using PCR with arbitrary primers. Nucl. Acids Res., n.18, p.7213-7218, 1990.

41 WILLIAMS, J. G. K.; KUBELIK, A. R.; LIVAK, K. J.; RAFALSKI, J. A. e TINGEY, S. V. DNA polymorphisms amplified by arbitrary primers are useful as genetic markers. Nucl. Acid. Res., n.18, p. 6531-6535, 1990.

42 WYMAN, A. R. e WHITE, R. A highly polymorphic locus in human DNA.Proc. Natl. Acad. Sci USA., n.77, p.6754- 6758, 1980. 